\title{
Iron-regulated Outer-membrane Proteins of Escherichia coli Strains Associated with Enteric or Extraintestinal Diseases of Man and Animals
}

\author{
By HENRIK CHART, $†$ PAULINE STEVENSON AND ELWYN GRIFFITHS* \\ National Institute for Biological Standards and Control, Blanche Lane, South Mimms, \\ Potters Bar, Hertfordshire EN6 3QG, UK
}

(Received 4 December 1987; revised 16 February 1988)

\begin{abstract}
The SDS-PAGE patterns of the iron-regulated outer-membrane proteins from 70 strains of Escherichia coli isolated from various human and animal infections were analysed and the nature of the siderophores produced was examined. Iron-regulated $81 \mathrm{kDa}$ and $74 \mathrm{kDa}$ protein bands seen in SDS-PAGE gels were characterized further by immunoblotting using anti-81 kDa and anti-74 kDa (Cir) sera. The results showed considerable differences between the patterns of the iron-regulated outer-membrane proteins exhibited by the different strains. Nevertheless, three distinct and characteristic profiles, based on the most prominent bands expressed, could be identified, although not all strains produced patterns which matched with one of these. These results suggest the possibility of using the pattern of iron-regulated outer-membrane proteins expressed, as well as siderophores produced, as a new set of markers to characterize groups of pathogenic E. coli.
\end{abstract}

\section{INTRODUCTION}

Many different pathogenic strains of Escherichia coli have been identified and these are known to be responsible for a variety of human and animal infections (Sussman, 1985). Properties reportedly associated with the virulence of these various pathogens include the possession of certain $\mathrm{O}$ and $\mathrm{K}$ antigens and their ability to produce specific adhesive factors, toxins or haemolysins. However, it is now known that the possession of a single trait is not sufficient for virulence and there is evidence that the pathogenicity of $E$. coli is a consequence of certain independent factors occuring together. Considerable attention has therefore been given to the analysis of various bacterial properties and to the grouping of isolates having similar characteristics (Stenderup \& Ørskov, 1983; Achtman et al., 1983, 1986; Korhonen et al., 1985; Vaisanen-Rhen et al., 1984; Achtman \& Pluschke, 1986; Selander et al., 1986; Valvano et al., 1986). Although some of these studies have revealed clonal groups of $E$. coli, no unique relationships between such clones and virulence or different clinical disease specificities have been identified (Achtman \& Pluschke, 1986). This has led to the suggestion that pathogenicity can be explained by the differential association of particular, and often unknown, bacterial properties with the individual clonal groupings (Achtman \& Pluschke, 1986).

In most studies to date, the properties of pathogenic $E$. coli have been examined in organisms grown in laboratory media and such characteristics may not correlate with the virulence of the strains. When bacterial pathogens multiply in vivo during infection they can be phenotypically quite different from the same organisms grown in laboratory media (Griffiths, 1983, 1987). Analysis of the properties of organisms grown in vivo should therefore add to our understanding of bacterial pathogenicity. One important environmental factor leading to this difference in phenotype is the availability of iron; the level of freely available iron in the healthy mammalian

†Present address: Public Health Laboratory Service, Division of Enteric Pathogens, Central Public Health Laboratory, 61 Colindale Avenue, London NW9 5EQ, UK. 
host is severely restricted. Many pathogens produce high-affinity iron-uptake systems when growing in iron-restricted environments both in vitro and in vivo during infection (Griffiths, 1987) and there is increasing evidence that these behave as virulence determinants. An essential feature of several of these systems is the synthesis and secretion of siderophores, together with the production of new outer-membrane proteins, some of which are receptors for ferricsiderophores and are essential for iron uptake.

Under iron-restricted growth conditions, pathogenic $E$. coli produce either the phenolic siderophore enterobactin alone, or they produce enterobactin plus the hydroxamate siderophore aerobactin (Williams, 1979; Braun, 1981; Griffiths, 1987). Generally, aerobactin production is associated with strains which cause extraintestinal infections, the necessary genes being located either on a plasmid or in the chromosome (Stuart et al., 1982; Montgomerie et al., 1984; Griffiths et al., 1985b; Carbonetti et al., 1986; Marolda et al., 1987). During iron restriction, $E$. coli also derepresses the synthesis of several outer-membrane proteins with molecular masses in the range $70-83 \mathrm{kDa}$. Some of these have been shown to be receptors for ferric siderophores, for example the $81 \mathrm{kDa}$ ferric-enterobactin receptor, whereas others, such as the $74 \mathrm{kDa}$ Cir protein, have no known function (Neilands, 1982). Previously, we reported a variation in the quantities of iron-regulated proteins produced by different $E$. coli strains, as well as differences in the SDS-PAGE patterns obtained from the very few pathogenic strains examined (Griffiths et al., 1983, 1985a; Chart \& Griffiths, 1985). In the study reported here, we examined these differences further by analysing SDS-PAGE patterns of iron-regulated outermembrane proteins from 70 strains of $E$. coli isolated from various human and animal infections.

\section{METHODS}

Bacterial strains and growth conditions. The $E$. coli strains used in this study are listed in Table 1 . Strains were stored at $-70^{\circ} \mathrm{C}$ in brain/heart infusion broth (Difco) containing glycerol $(10 \%, \mathrm{v} / \mathrm{v})$ and grown in trypticase soy broth (BBL Microbiology Systems); ferric dicitrate $(25 \mu \mathrm{M})$ was added when producing iron-replete organisms in order to ensure a plentiful supply of iron. Expression of iron-regulated outer-membrane proteins was induced by growing bacteria in trypticase soy broth $\left(37^{\circ} \mathrm{C}, 6 \mathrm{~h}\right)$ containing the iron-chelator Desferal (0.5 mM, Ciba-Geigy). Bacteria were also grown in the Tris-buffered medium of Simon \& Tessman (1963) supplemented with sodium succinate $\left(10 \mathrm{~g}^{-1}, \mathrm{pH} 6.8\right)$. The rationale for using a Tris/succinate medium is discussed by Braun (1981) and Neilands (1982).

Electrophoresis of outer-membrane proteins. Outer membranes were prepared using Triton X-100 as described by Griffiths et al. (1983) or using sodium lauryl sarcosinate (Filip et al., 1973); similar outer-membrane protein profiles were obtained by both procedures. Where indicated in the text, the protease inhibitors phenylmethylsulphonyl fluoride (PMSF) (10 mM) or benzamidine (10 mM) were added to the buffer medium prior to sonication.

Table 1. Strains of E. coli isolated from animal and human sources

\begin{tabular}{|c|c|c|c|c|}
\hline $\begin{array}{c}\text { Strain } \\
\text { designation* }\end{array}$ & Serotype & Source $†$ & $\begin{array}{c}\text { Membrane } \\
\text { pattern (MP) } \ddagger\end{array}$ & $\begin{array}{l}\text { Siderophore } \\
\text { production§ }\end{array}$ \\
\hline \multicolumn{5}{|l|}{ Human } \\
\hline 1. $\mathrm{O} 111^{a}$ & $\mathrm{O} 111: \mathrm{K} 58: \mathrm{H} 2$ & EPEC & - & ent \\
\hline 2. $\mathrm{SC} 48^{b}$ & 015 & NHF & - & ent \\
\hline 3. $13^{b}$ & $\mathrm{O} 128: \mathrm{K} 67: \mathrm{H} 2$ & EPEC & - & ent \\
\hline 4. $10407^{c}$ & O78:K2:H11 & ETEC & - & ent \\
\hline 5. $\mathrm{E} 16970 / \mathrm{O}^{c}$ & $\mathrm{O} 25: \mathrm{H}^{-}$ & ETEC & - & ent \\
\hline 6. $\mathrm{E} 25079 / \mathrm{O}^{c}$ & O6:H16 & ETEC & - & ent \\
\hline 7. A112d & $01: \mathbf{K} 1$ & NHF & 5 & ent \\
\hline 8. $\mathrm{A} 194^{d}$ & $\mathbf{O} 1: \mathbf{K} 1$ & NHF & 5 & ent \\
\hline 9. $\mathrm{A} 25^{d}$ & $\mathrm{O} 1: \mathrm{K} 1$ & UTI & 9 & ent/aero \\
\hline 10. $\mathrm{A} 266^{d}$ & O1: K1 & UTI & 9 & ent/aero \\
\hline 11. $\mathrm{A} 265^{d}$ & $\mathrm{O} 1: \mathrm{K} 1$ & UTI & 9 & ent/aero \\
\hline 12. $\mathrm{A} 100^{d}$ & $\mathrm{O} 1: \mathrm{K} 1$ & UTI & 9 & ent/aero \\
\hline 13. $\mathrm{A} 190^{d}$ & $\mathrm{O} 1: \mathbf{K} 1$ & UTI & 9 & ent/aero \\
\hline 14. $\mathrm{A} 174^{d}$ & $\mathrm{O} 18: \mathrm{K} 1$ & UTI & 6 & ent \\
\hline 15. $\mathrm{A} 155^{d}$ & $\mathrm{O} 18: \mathrm{K} 1$ & UTI & 6 & ent $\|$ \\
\hline 16. $\mathrm{A} 294^{d}$ & $\mathrm{O} 18: \mathrm{K} 1$ & UTI & 6 & ent $\|$ \\
\hline 17. $\mathrm{A} 292^{d}$ & $\mathrm{O} 18: \mathrm{K} 1$ & UTI & 6 & ent $\|$ \\
\hline 18. $\mathrm{A} 300^{d}$ & $\mathrm{O} 18: \mathrm{K} 1$ & UTI & 6 & ent $\|$ \\
\hline
\end{tabular}




\begin{tabular}{|c|c|c|c|c|}
\hline 19. $\mathrm{A} 105^{d}$ & $\mathrm{O} 18: \mathrm{K} 1$ & UTI & 9 & ent/aero \\
\hline 20. $\mathrm{Al}^{106^{d}}$ & $018: \mathrm{K} 1$ & UTI & 9 & ent/aero \\
\hline 21. $A 53^{d}$ & $018: \mathrm{K} 1$ & NBM & 9 & ent/aero \\
\hline 22. $\mathrm{A} 54^{d}$ & $018: K 1$ & NBM & 9 & ent/aero \\
\hline 23. $\mathbf{A} 58^{d}$ & O18:K1 & NBM & 9 & ent/aero \\
\hline 24. A59 & O18:K1 & NBM & 9 & ent/aero \\
\hline 25. $\mathrm{A}^{6} 0^{d}$ & $\mathrm{O} 18: \mathrm{K} 1$ & NBM & 9 & ent/aero \\
\hline 26. $780401^{e}$ & O18 :K1 & NBM & - & ent/aero \\
\hline 27. $\mathrm{H} 247^{f}$ & O18 :K1 & NBM & - & ent/aero \\
\hline 28. $536^{\circ}$ & O6 & UTI & - & ent \\
\hline $29.477^{\circ}$ & 018 & UTI & - & ent/aero \\
\hline $30.764^{g}$ & 018 & UTI & - & ent/aero \\
\hline $31.275^{\circ}$ & 075 & UTI & - & ent/aero \\
\hline 32. $341^{g}$ & $\mathbf{O} 75$ & UTI & - & ent \\
\hline 33. $367^{g}$ & O4 & UTI & - & ent \\
\hline \multicolumn{5}{|l|}{ Animal } \\
\hline 34. B44f & O9:K30:K99 & Bovine $\mathrm{E}$ & - & ent \\
\hline 35. $\mathrm{B} 85^{\prime}$ & O9:K35:K99 & Bovine $\mathrm{E}$ & - & ent \\
\hline 36. B79 & O101:K32:K99 & Bovine $\mathrm{E}$ & - & ent \\
\hline 37. B41f & O101:K30:K99 & Bovine E & - & ent \\
\hline 38. $\mathrm{S} 3^{f}$ & O8 :K85:K99 & Ovine E & - & ent \\
\hline 39. $\mathrm{A} 82^{h}$ & O8 :K85 :K99 & Ovine E & - & ent \\
\hline 40. $\mathrm{P} 18^{f}$ & O8:K87:K88ab & Porcine E & - & ent \\
\hline 41. P\&f & $0138: K 81$ & Porcine $\mathrm{O}$ & - & ent \\
\hline 42. $\mathrm{P} 14^{f}$ & O147:K89:K88ac & Porcine E & - & ent \\
\hline 43. $P 115 f$ & O149:K91 :K88ac & Porcine E & - & ent \\
\hline 44. P3f & O139:K82 & Porcine $\mathrm{O}$ & - & ent \\
\hline 45. Abbotstown ${ }^{h}$ & O149:K91 :K88ac & Porcine E & - & ent \\
\hline 46. $\mathrm{G} 7^{h}$ & O8:K87:K88ab & Porcine E & - & ent \\
\hline 47. $\mathrm{B} 184^{f}$ & O78 : K80 & Bovine B/S & - & ent/aero \\
\hline 48. B190 & O78:K80 & Bovine B/S & - & ent/aero \\
\hline 49. B179r & O78 :K80 & Bovine B/S & - & ent/aero \\
\hline 50. B197f & O78 :K80 & Bovine $\mathrm{B} / \mathrm{S}$ & - & ent/aero \\
\hline 51. B188 & O78 :K80 & Bovine B/S & - & ent/aero \\
\hline 52. X136/85 & O78 :K80 & Bovine B/S & - & ent/aero \\
\hline 53. RVC95 ${ }^{h}$ & O26:K60 & Bovine B/S & - & ent \\
\hline 54. $.3^{f}$ & O78 :K80 & Ovine $B / S$ & - & ent \\
\hline 55. $\mathrm{S}^{f}$ & O78 : K80 & Ovine $\mathbf{B} / \mathbf{S}$ & - & ent \\
\hline 56. $S 2^{f}$ & O78 :K80 & Ovine B/S & - & ent/aero \\
\hline 57. RVC330 ${ }^{h}$ & O78:K80 & Ovine $\mathbf{B} / \mathbf{S}$ & - & ent/aero \\
\hline 58. $\mathrm{S5}^{h}$ & O15:K & Ovine B/S & - & ent \\
\hline 59. $\mathrm{F}^{h}$ & O1:K1 & Chicken B/S & - & ent/aero \\
\hline 60. $\mathrm{P} 21^{f}$ & O141:K85 & Porcine $\mathrm{O}$ & - & ent \\
\hline 61. P25f & O141:K85 & Porcine $\mathrm{O}$ & - & ent \\
\hline 62. $\mathrm{P} 26^{f}$ & $0141: K 85$ & Porcine $\mathrm{O}$ & - & ent \\
\hline 63. $\mathrm{P} 27^{f}$ & $0141: K 85$ & Porcine $\mathrm{O}$ & - & ent \\
\hline 64. P28f & $0141:$ K85 & Porcine $\mathrm{O}$ & - & ent \\
\hline 65. P58f & $0141: K 85$ & Porcine $\mathrm{O}$ & - & ent \\
\hline 66. P60 & $0141:$ K85 & Porcine $\mathrm{O}$ & - & ent \\
\hline 67. $\mathrm{P} 61^{f}$ & $0141:$ K85 & Porcine $\mathrm{O}$ & - & ent \\
\hline 68. P62f & $0141:$ K85 & Porcine $\mathrm{O}$ & - & ent \\
\hline 69. P63f & $0141: K 85$ & Porcine $\mathrm{O}$ & - & ent \\
\hline 70. $\mathrm{P} 23^{f}$ & O141:K85 & Porcine $\mathrm{O}$ & - & ent \\
\hline
\end{tabular}

* The sequential numbers used here are for ready reference in the text and figures. The original strain designations are those from the source laboratories. Source laboratories are indicated by superscript letters: $a$, This laboratory; $b$, J. Dolby, Clinical Research Centre, Harrow, UK; $c$, S. M. Scotland, Central Public Health Laboratory, Colindale, London, UK; $d, \mathrm{M}$. Achtman, Max-Planck Institute, Berlin, West Germany; $e, \mathrm{H}$. C. Zanen, University of Amsterdam, The Netherlands; $f, \mathrm{H}$. Williams Smith, Houghton Research Station, Huntingdon, UK; $g$, J. Hacker, University of Würzburg, W. Germany; $h$, J. A. Morris, Central Veterinary Laboratory, Weybridge, Surrey, UK.

† B/S, bacteraemia/septicaemia; E, enteropathogen; EPEC, enteropathogenic; ETEC, enterotoxigenic; NBM, new-born meningitis; NHF, normal human faeces; O, oedema disease; UTI, urinary tract infection.

¥ Major outer-membrane protein classification; see Achtman et al. (1983).

$\S$ ent, produces enterobactin; aero, produces aerobactin.

\| Requires niacin for growth. 
Benzamidine retards proteolytic degradation of the $81 \mathrm{kDa}$ protein of $E$. coli K12 (Hollifield et al., 1978). Outermembrane proteins were analysed by SDS-PAGE using the extended electrophoresis times described by Griffiths et al. (1985a). The iron-regulated $81 \mathrm{kDa}$ and $74 \mathrm{kDa}$ outer-membrane proteins of $E$. coli O111 (Chart \& Griffiths, 1985) were used as molecular mass markers. After electrophoresis, the gels were either stained with Coomassie Blue or used for immunoblotting. Immunoblotting was done essentially as described by Stevenson \& Griffiths (1985) with antiserum raised in rabbits with the $81 \mathrm{kDa}$ or the $74 \mathrm{kDa}$ (Cir) protein of E. coli O111:K58:H2; the reaction with the second antibody, goat anti-rabbit immunoglobulin G (Miles Laboratories), was carried out for $24 \mathrm{~h}$. The $81 \mathrm{kDa}$ and $74 \mathrm{kDa}$ proteins of $E$. coli 0111 were purified by preparative SDS-PAGE as described by Chart \& Griffiths (1985).

Assay for siderophore production. Enterobactin was assayed using the Arnow test for the detection of phenolic compounds (Arnow, 1937). The hydroxamate siderophore aerobactin was assayed using the ferric perchlorate test (Atkin et al., 1970).

Haemolysin production. This was assessed by growing strains on trypticase soy agar plates containing $5 \%(\mathrm{v} / \mathrm{v})$ washed horse or sheep erythrocytes. Cultures were examined for zones of haemolysis following incubation at $37^{\circ} \mathrm{C}$ for $24 \mathrm{~h}$.

\section{RESULTS}

\section{Analysis of iron-regulated outer-membrane proteins from $E$. coli strains of human origin}

Strains of $E$. coli representing the various groups pathogenic for humans, as well as isolates from normal human faeces, were grown under iron-restricted conditions in order to examine the expression of iron-regulated outer-membrane proteins. The strains studied produced new outermembrane proteins with molecular masses in the region of 70-83 $\mathrm{kDa}$ during growth in the presence of the iron chelator Desferal (Fig. 1). A comparison of a number of strains showed that when the organisms were grown under iron-replete conditions these proteins were either not expressed or were expressed at an extremely low level (for example see Fig. $2 a$ ), as has been shown previously with other strains (Griffiths et al., 1983, 1985a, $b$; Neilands, 1982). Figs 1 and 2(a) also show striking differences in the protein pattern produced on SDS-PAGE by the various $E$. coli strains. The identity of the $81 \mathrm{kDa}$ and $74 \mathrm{kDa}$ (Cir) proteins was confirmed by immunoblotting using a polyclonal anti-81 kDa serum (Chart \& Griffiths, 1985) and an anti$74 \mathrm{kDa}$ (Cir) serum (Griffiths et al., 1985b); representative strains exhibiting both of these proteins are shown in Fig. 2(b).

Although there were quantitative and qualitative differences in the iron-regulated proteins expressed by the various isolates, three characteristic patterns could be consistently distinguished (Fig. $2 a$ ). The protein profiles produced by the enterotoxigenic, enteropathogenic and commensal strains of $E$. coli studied are shown in Fig. 1, lanes 1-8. The SDS-PAGE profiles in lanes 1-6 are similar to each other in that the predominant iron-regulated proteins expressed are the $81 \mathrm{kDa}$ and $74 \mathrm{kDa}$ (Cir) proteins, the identity of which was confirmed by immunoblotting; traces of a $78 \mathrm{kDa}$ and an $83 \mathrm{kDa}$ protein can also be seen in some instances, and strain 2 has an additional iron-regulated protein of about $71 \mathrm{kDa}$. The characteristic profile expressed by the majority of these strains is typified by that of E. coli $\mathrm{O} 25: \mathrm{H}^{-}$(Table 1, strain 5; Fig, 2a, $b$, lane 1).

The most prominent iron-regulated proteins seen in profiles $7-13$ in Fig. 1 are those with molecular masses of approximately $70 \mathrm{kDa}$ and $74 \mathrm{kDa}$, together with a slightly weaker band of about $71 \mathrm{kDa}$. This type of protein profile is typified by that of E. coli O1 :K1 (Table 1, strain 12, Fig. $2 a, b$, lane 2). All of the strains whose profiles are seen in lanes 7-13 of Fig. 1 belong to serotype $\mathrm{Ol}: \mathrm{K} 1$, and all, except those in lanes 7 and 8 , were isolated from urinary tract infections. All except one of these strains produced small amounts of an $81 \mathrm{kDa}$ protein, although this protein band was not always easily seen. The presence of an $81 \mathrm{kDa}$ protein, which is the receptor for ferric-enterobactin, was confirmed by immunoblotting (Fig. 3) using the polyclonal anti-81 $\mathrm{kDa}$ serum. However, this antiserum failed to detect an $81 \mathrm{kDa}$ protein in the outer-membrane protein profile of $E$. coli $\mathrm{O} 1: \mathrm{K} 1$ strain A25 (Table 1, Figs 1, and 3, strain 9). The antiserum raised with the $74 \mathrm{kDa}$ (Cir) protein of $E$. coli $\mathrm{O} 111$ as antigen reacted with the $74 \mathrm{kDa}$ protein produced by $E$. coli strains $9-13$ but failed to recognize the protein of approximately $74 \mathrm{kDa}$ in strains 7 and 8 (Table 1, Fig. 3), which means that these two strains 


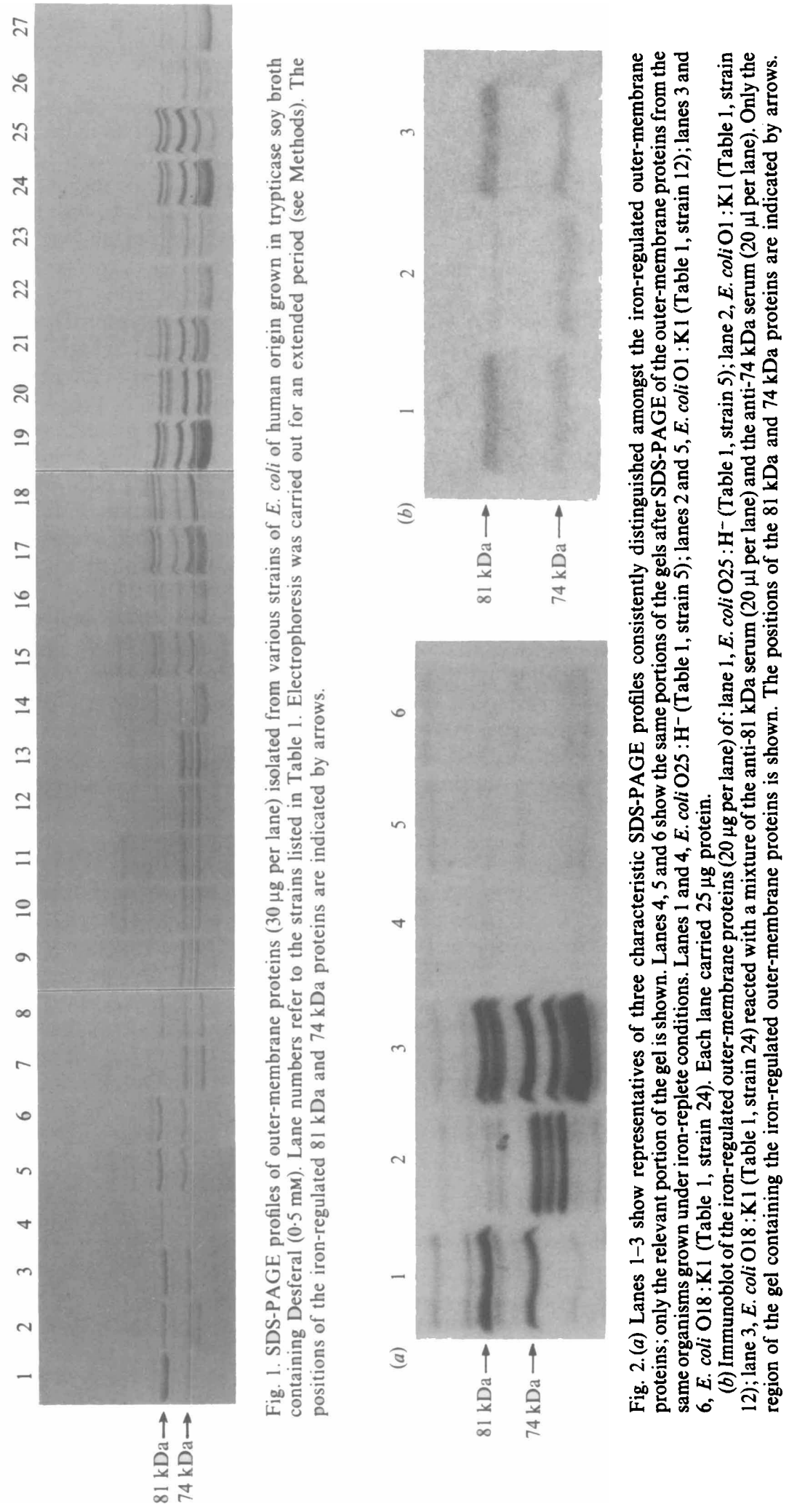


cannot be considered as having an iron-regulated outer-membrane protein profile like that shown in Fig. 2(a), lane 2. It should be noted that strains 7 and 8 also have a different major outermembrane protein pattern from strains 9-13 (Table 1, MP5 and MP9).

The SDS-PAGE profiles of proteins expressed under iron restriction by $E$. coli strains 14-27 (Fig. 1, lanes 14-27) show four to six prominent bands, with molecular masses in the range 68$83 \mathrm{kDa}$, and they are quite distinct from those of strains 1-13; Fig. 2(a), lane 3, shows an example of this type of profile. E. coli strains 14-27 all belong to the $018: \mathrm{K} 1$ serogroup and were isolated from urinary tract infections (strains 14-20) or from newborn infants with meningitis (strains 21-27). Each produced an $81 \mathrm{kDa}$ and a $74 \mathrm{kDa}$ (Cir) protein during iron-restricted growth, as confirmed by immunoblotting. Most, but not all, of these strains expressed a $68 \mathrm{kDa}$ protein (Fig. 1, compare lanes 18 and 19), but there is some doubt whether this protein is regulated by iron since varying quantities can be seen under iron-replete growth conditions. Also, a doublet can be seen in the region of the $78 \mathrm{kDa}$ band in several strains. Interestingly, $E$. coli strains showing a doublet $78 \mathrm{kDa}$ band belong to clonal type O18:K1 MP9 (Achtman et al., 1983); clonal type O18:K1 MP6 strains appear to have a single band in this region. The possibility that protein degradation during the isolation of the membrane proteins might have been responsible for producing this type of profile was tested by including protease inhibitors in the reagents used. Degradation of the $81 \mathrm{kDa}$ protein in $E$. coli $\mathrm{K} 12$ has been reported by Hollifield et al. (1978) and this proteolysis was inhibited by benzamidine. However, the presence of the protease inhibitors benzamidine or PMSF in the reagents used for preparation of outermembrane proteins had no effect on the production of the multiple-band pattern of ironregulated proteins observed here.

E. coli strains numbered 28, 32 and 33 (Table 1) exhibited iron-regulated outer-membrane proteins similar to those of strains 14-27 (data not shown). These organisms were again isolates from cases of urinary tract infections but they belonged to different serogroups $(06,075$ and O4). They did not produce the $68 \mathrm{kDa}$ protein seen in the SDS-PAGE profile of most of the $E$. coli $\mathrm{O} 18: \mathrm{K} 1$ strains. Two $E$. coli $\mathrm{O} 18$ strains which were $\mathrm{K} 1$ negative (Table 1 , strains 29 and 30) exhibited a iron-regulated protein pattern identical to those produced by strains $9-13$, as did another isolate of $E$. coli O75 (Table 1, strain 31; data not shown). All of these strains produced an $81 \mathrm{kDa}$ and a $74 \mathrm{kDa}$ (Cir) protein as identified by immunoblotting.

\section{Analysis of iron-regulated outer-membrane proteins from E. coli strains of animal origin}

Fig. 4 shows that the majority of animal strains examined expressed outer-membrane proteins with molecular masses in the region of 74-83 kDa when grown in broth containing Desferal. The iron-regulated outer-membrane proteins of $E$. coli O111 (Fig. 4, lane 1) were used as molecular mass markers. As before, a comparison of a number of strains showed that these proteins were not expressed when the organisms were grown under iron-replete conditions (data not shown). Although some variation between the pattern of proteins produced by different strains can be seen, the striking differences in the SDS-PAGE profiles produced by the various human isolates were notobserved (compare Figs 1 and $2 a$ with Fig. 4). Many strains, viz. 34-37, 40,42, 58, 59, as well as a group of 10 isolates of $E$. coli serotype O141:K85 (Table 1, strains 60-69; data not shown), produced an iron-regulated outer-membrane profile like that exhibited by the $025: \mathrm{H}^{-}$strain 5 (Fig. $2 a$, lane 1); these produced both the $81 \mathrm{kDa}$ and $74 \mathrm{kDa}$ (Cir) proteins.

In other instances, although there was clearly variation between isolates, no well-defined patterns could be discerned. For example, two E. coli O8:K85:K99 strains (Fig. 4, lanes 38 and 39) seemed not to express a $74 \mathrm{kDa}$ protein and the anti-74 $\mathrm{kDa}$ (Cir) serum failed to react with a band in this region on immunoblotting (data not shown). Again, two isolates of $E$. coli O149:K91:K88ac, as well as an O26:K60 strain, showed a doublet protein band at approximately $74 \mathrm{kDa}$ (Fig. 4, lanes 43,45 and 53), and two of the ten E. coli O78:K80 isolates produced a doublet band in the region of the $78 \mathrm{kDa}$ protein (Fig. 4, lanes 48 and 56). Proteins of $74 \mathrm{kDa}$ from $E$. coli $\mathrm{O} 78$ isolates $48,50,52,56$ and 57 failed to react with the anti-74 kDa serum. All other strains which produced a $74 \mathrm{kDa}$ band reacted with this antiserum. One isolate of $E$. coli $\mathrm{O} 141$ : K85 (Table 1, strain 70) did not show a $74 \mathrm{kDa}$ protein on SDS-PAGE and no protein band in this region reacted with the anti-74 $\mathrm{kDa}$ serum on immunoblotting (data not shown). 


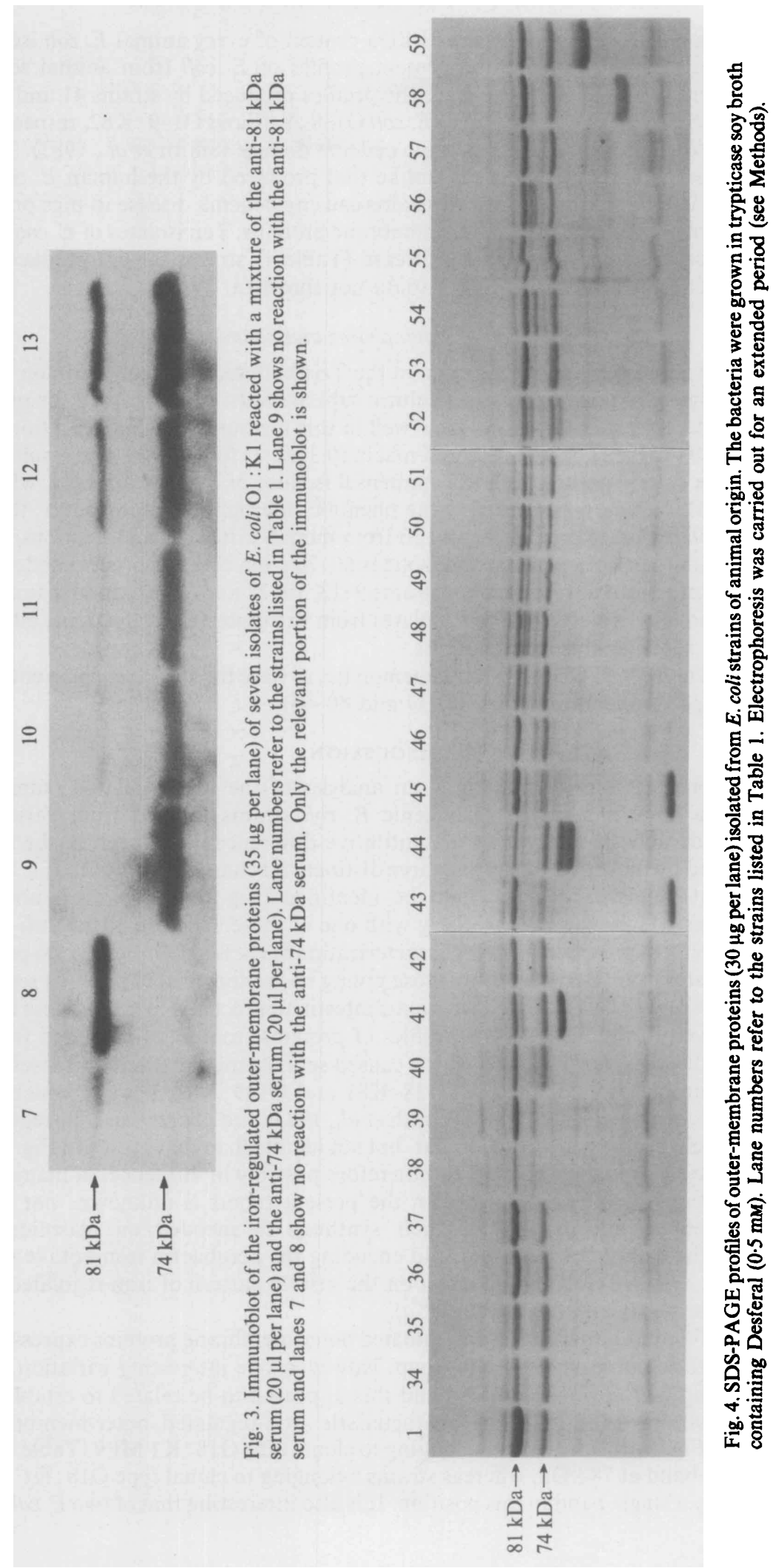


The anti-81 kDa serum reacted with the $81 \mathrm{kDa}$ protein of every animal $E$. coli isolate tested.

Two iron-regulated outer-membrane protein profiles of $E$. coli from animal sources were distinctly different from the rest. These are the profiles produced by strains 41 and 44 (Fig. 4). Interestingly, these two patterns belong to $E$. coli $\mathrm{O} 138: \mathrm{K} 81$ and $\mathrm{O} 139: \mathrm{K} 82$, respectively, both of which were isolated from cases of porcine oedema disease (Smith et al., 1983). The pattern produced by these two organisms is not unlike that produced by the human $E$. coli $018: \mathrm{K} 1$ strains (Fig. 2a, lane 3). However, not all strains causing oedema disease in pigs produced this particular pattern of iron-regulated outer-membrane proteins. Ten isolates of $E$. coli $\mathrm{O} 141: \mathrm{K} 85$ obtained from cases of porcine oedema disease (Table 1, strains 60-69) produced a profile identical to that seen in Fig. 2(a), lane 1 (data not shown).

\section{Production of siderophores and haemolysin}

The various strains of $E$. coli were grown in the Tris-buffered medium of Simon \& Tessman (1963) containing sodium succinate, and culture supernatants were analysed for phenolic and hydroxamate siderophores. All strains grew well in this medium with the exception of strain 2 and strains 14-18 (Table 1), which required niacin $\left(0.3 \mathrm{~g}^{-1}\right)$ for growth. The results in Table 1 show that all the enteric pathogens and commensal isolates of $E$. coli examined, whether from human or animal sources, produced only the phenolic siderophore enterobactin; this was also the case with isolates 14-18 and 28, 32 and 33 from human urinary tract infections, isolates 53, 55 and 58 from animal septicaemias, and isolates 60-70 from cases of porcine oedema disease. Aerobactin was produced only by human strains 9-13, 19-27 and 29-31, and by animal isolates 47-52, 56, 57 and 59 (Table 1); all were isolates from extraintestinal infections, either urinary tract infections, septicaemias or meningitis.

Isolates 14-18 and 28-33 (Table 1) were haemolytic, as were the strains causing enteric disease in sheep and pigs (Table 1, numbers 38,39 and 40-46).

\section{DISCUSSION}

This paper presents for the first time, an analysis of the iron-regulated outer-membrane proteins from a large number of pathogenic $E$. coli strains isolated from various sources. Although considerable qualitative and quantitative differences were seen in the SDS-PAGE profiles exhibited by the different strains, three distinct and characteristic patterns, based on the most prominent bands expressed, could be identified (Fig. 2a). However, not all strains produced profiles which matched precisely with one of these. The use of the anti-81 kDa and anti-74 $\mathrm{kDa}(\mathrm{Cir})$ sera provided further characterization of the $81 \mathrm{kDa}$ and $74 \mathrm{kDa}$ proteins seen. Among the isolates examined here, only those giving rise to the protein patterns seen in lanes 2 or 3 of Fig. 2(a) seem to be associated with extraintestinal infections in man. These two patterns were not observed in the SDS-PAGE profiles of proteins from $E$. coli isolated from cases of human enteric diseases, nor in $E$. coli which caused septicaemia or enteric diseases of animals. However, two animal isolates, $E$. coli $0138: \mathrm{K} 81$ and $\mathrm{O} 139: \mathrm{K} 82$, both of which are strains associated with oedema disease in pigs (Smith et al., 1983), did express an iron-regulated outermembrane protein profile which was similar, but not identical, to that shown in Fig. 2(a), lane 3. The role in bacterial iron metabolism, and therefore possibly in virulence, of many of the ironregulated membrane proteins described in the present report is unknown; nor is it known whether the genetic information for their synthesis is encoded on plasmids or in the chromosome. The loss of the ColV plasmid encoding the aerobactin iron-uptake system from one strain of $E$. coli $\mathrm{O} 18: \mathrm{K} 1$ had no effect on the visible pattern of iron-regulated membrane proteins it expressed (Griffiths et al., 1985a).

Clearly, the different patterns of iron-regulated outer-membrane proteins expressed by $E$. coli are not restricted to one particular serogroup. However, one interesting variation amongst an established group of $E$. coli was noticed and this appeared to be related to established clonal types. $E$. coli strains exhibiting the characteristic iron-regulated outer-membrane protein pattern seen in Fig. 2 (a), lane 3, and belonging to clonal type O18:K1 MP9 (Table 1), showed a doublet protein band at $78 \mathrm{kDa}$, whereas strains belonging to clonal type O18:K1 MP6 (Table 1) produced only a single band in this position. It is also interesting that of two E. coli $\mathrm{O} 6$ isolates 
examined, one, a human enterotoxigenic strain (Table 1, strain 6), produced a protein profile like that in Fig. 2(a), lane 1, whereas the other, an isolate from a case of human urinary tract infection (Table 1, strain 28), gave a protein pattern similar to that seen in Fig. 2(a), lane 3. Again, all five $E$. coli $\mathrm{O} 1: \mathrm{K} 1$ isolates from human urinary tract infections (Table 1, strains 9-13) exhibited iron-regulated outer-membrane protein profiles like that represented in Fig. 2(a), lane 2 , but the one $\mathrm{O} 1: \mathrm{K} 1$ strain of animal origin, from chicken septicaemia (Table 1, strain 59) showed an iron-regulated protein profile like that in Fig. $2(a)$ lane 1. One human isolate of $E$. coli $\mathrm{O} 1$ :K1 (Table 1, strain 9) appeared not to produce an $81 \mathrm{kDa}$ protein, the receptor for ferric enterobactin, although it did synthesize this chelator as well as aerobactin. Not only was there no $81 \mathrm{kDa}$ protein visible on SDS-PAGE of membrane proteins from this strain, but no reaction was observed on immunoblotting with the anti-81 $\mathrm{kDa}$ serum. This antiserum reacts with all other $81 \mathrm{kDa}$ proteins found so far (Chart \& Griffiths, 1985; this paper), as well as with an ironregulated $81 \mathrm{kDa}$ protein in 17 clinical isolates of Klebsiella pneumoniae (Williams et al., 1987) and an $81 \mathrm{kDa}$ protein from Salmonella typhimurium (Chart \& Griffiths, 1985). It is unlikely, therefore, that this antiserum failed to recognize the enterobactin receptor, if present. $E$. coli strain 9 (Table 1) is therefore unusual in that it is the only one of more than 70 clinical isolates examined which failed to produce the $81 \mathrm{kDa}$ protein. Less is known about the specificity of the antiserum raised to the $74 \mathrm{kDa}(\mathrm{Cir})$ protein of $E$. coli $\mathrm{O} 111$. The fact that it failed to react on immunoblotting with a number of $74 \mathrm{kDa}$ proteins indicates either that there is antigenic variation amongst these proteins, or that the $74 \mathrm{kDa}$ protein seen on SDS-PAGE is not the $74 \mathrm{kDa}$ (Cir) protein. It is already known that the plasmid-encoded aerobactin receptor protein is a $74 \mathrm{kDa}$ protein (Bindereif et al., 1982; Grewal et al., 1982). Work is in progress to characterize further the $74 \mathrm{kDa}$ proteins exhibited by the various strains.

Our data on the nature of the siderophore or siderophores produced by these various isolates are in general agreement with previous reports (Stuart et al., 1982; Montgomerie et al., 1984; Carbonetti et al., 1986; Linggood et al., 1987). All of the strains in our study produced the iron chelator enterobactin but only those strains causing extraintestinal infections produced the additional hydroxamate-type chelator, aerobactin. However, not all strains isolated from extraintestinal infections were aerobactin producers. Five $E$. coli $\mathrm{O} 18: \mathrm{K} 1$ strains isolated from human urinary tract infections failed to produce aerobactin; these organisms exhibited the major outer-membrane protein group 6(MP6) (Achtman et al., 1983), required niacin for growth in the Tris/succinate medium and produced only enterobactin during iron restriction (Table 1 , strains 14-18). Interestingly, Valvano et al. (1986) have recently reported that of $12 \mathrm{E}$. coli $018: \mathrm{K} 1$ strains exhibiting outer-membrane protein pattern MP6 examined by them none contained a functional aerobactin iron-uptake system. Two of these $E$. coli $\mathrm{O} 18: \mathrm{K} 1 \mathrm{MP9}$ strains (Valvano et al., 1986) did however produce aerobactin, a result which is consistent with our data on seven E. coli O18:K1 MP9 strains (Table 1). In agreement with Achtman et al. (1983) and Valvano et al. (1986) we also found that $E$. coli O18:K1 MP6 strains were haemolytic. Another group of isolates in our study, again from human urinary tract infections, strains 28-33 (Table 1), produced haemolysins which lysed both horse and sheep erythrocytes. Three of these strains (two $\mathrm{O} 18$ and one $\mathrm{O75}$ ) also produced aerobactin. However, four strains isolated from cases of bovine or ovine septicaemia did not produce aerobactin nor were they haemolytic (Table 1, strains 53, 54, 55 and 58). These strains may have lost plasmid-determined aerobactin genes during laboratory subculture. However, Linggood et al. (1987) have identified a number of animal isolates which were negative for aerobactin production although positive by colony hybridization for the aerobactin genetic determinants; they suggest that such strains may be mutated.

In conclusion, our results show the distribution of a new set of markers, the iron-regulated outer-membrane proteins, together with siderophore production, amongst previously established clones and other pathogenic strains of $E$. coli of unknown clonal types. Such characteristics should be taken into consideration when attempts are made to group pathogenic $E$. coli according to parameters which may be important for virulence. We believe that analysis of organisms grown in an iron-restricted environment, a condition known to resemble more closely that usually found in host tissues, will add considerably to the study of pathogenic $E$. coli, 
and other pathogens, and may give a clearer insight into bacterial characteristics associated with virulence and with different disease specificities. Such an analysis has already proved useful in studying the properties of Shigella flexneri and enteroinvasive $E$. coli (Griffiths et al., 1985b; Marolda et al., 1987; Nassif et al., 1987; Lawlor et al., 1987).

We gratefully acknowledge the generous gifts of strains from our colleagues listed in Table 1 and thank the Medical Research Council and the World Health Organization for financial support.

\section{REFERENCES}

ARnow, L. E. (1937). Colorimetric determination of the components of 3,4-dihydroxyphenylalaninetyrosine mixtures. Journal of Biological Chemistry 228, 531-537.

Achtman, M. \& Pluschke, G. (1986). Clonal analysis of descent and virulence among selected Escherichia coli. Annual Review of Microbiology 40, 185-210.

Achtman, M., Mercer, A., Kusecek, B., Pohl, A., Heuzenroeder, M., Aaronson, W., Sutton, A. \& SILVER, R. P. (1983). Six widespread bacterial clones among Escherichia coli $\mathrm{K} 1$ isolates. Infection and Immunity 39, 315-335.

Achtman, M., Heuzenroeder, M., Kusecek, B., Ochman, H., Caugant, D., Selander, R. K., Vaisanen-RHen, V., Korhonen, T. K., Stuart, S., ØRSKOV, F. \& ØRSKOV, I. (1986). Clonal analysis of Escherichia coli $\mathrm{O} 2: \mathrm{K} 1$ isolated from diseased humans and animals. Infection and Immunity 51, 268276.

AtKIn, C. L., Neilands, J. B. \& Phaff, H. J. (1970). Rhodotorulic acid from species of Leucosporidium, Rhodosporidium, Rhodotorula, Sporidiobolus and Sporobolomyces and a new alanine-containing ferrichrome from Cryptococcus melibiosium. Journal of Bacteriology 103, 722-733.

Bindereif, A., Braun, V. \& HaNTKe, K. (1982). The cloacin receptor of ColV-bearing Escherichia coli is part of the $\mathrm{Fe}^{3+}$-aerobactin transport system. Journal of Bacteriology 150, 1472-1475.

BraUn, V. (1981). Escherichia coli cells containing the plasmid ColV produce the ionophore aerobactin. FEMS Microbiology Letters 11, 225-228.

Carbonetti, N. H., Boonchai, S., Parry, S. H., VAISANEN-RHEN, V., KORHONEN, T. K. \& WilliaMS, P. H. (1986). Aerobactin-mediated iron uptake by Escherichia coli isolates from human extra-intestinal infections. Infection and Immunity 51, 966-968.

CharT, H. \& Griffiths, E. (1985). Antigenic and molecular homology of the ferric enterobactin receptor protein of Escherichia coli. Journal of General Microbiology 131, 1503-1509.

Filip, C., Fletcher, G., WulfF, J. L. \& Earhart, C. F. (1973). Solubilization of the cytoplasmic membrane of Escherichia coli by the ionic detergent sodium lauryl sarcosinate. Journal of Bacteriology 115, 717-722.

Grewal, K. K., Warner, P. J. \& Williams, P. H. (1982). An inducible outer membrane protein involved in aerobactin mediated iron transport by ColV strains of Escherichia coli. FEBS Letters 140, 27-30.

GRIFFITHS, E. (1983). Adaptation and multiplication of bacteria in host tissues. Philosophical Transactions of the Royal Society B303, 85-96.
GriffITHS, E. (1987). The iron-uptake systems of pathogenic bacteria. In Iron and Infection; Molecular, Physiological and Clinical Aspects, pp. 69-137. Edited by J. J. Bullen \& E. Griffiths. Chichester: Wiley.

Griffiths, E., Stevenson, P. \& JoyCe, P. (1983). Pathogenic Escherichia coli express new outer membrane proteins when growing in vivo. FEMS Microbiology Letters 16, 95-99.

Griffiths, E., Stevenson, P., Thorpe, R. \& Chart, H. (1985a). Naturally occuring antibodies in human sera that react with the iron regulated outer membrane proteins of Escherichia coli. Infection and Immunity 47, 808-813.

Griffiths, E., Stevenson, P., Hale, T. L. \& Formal, S. B. $(1985 b)$. Synthesis of aerobactin and a 76000dalton iron-regulated outer membrane protein by Escherichia coli K12-Shigella flexneri hybrids and by enteroinvasive strains of Escherichia coli. Infection and Immunity 49, 67-71.

Hollifield, W. C., JR, Fiss, E. H. \& Neilands, J. B. (1978). Modification of a ferric enterobactin receptor protein from the outer membrane of Escherichia coli. Biochemical and Biophysical Research Communications 83, 739-746.

Korhonen, T. K., Valtonen, M. V., Parkininen, J., Vaisanen-RHEN, V., FinNe, J., Ørskov, F., Ørskov, I., Svenson, S. B. \& Makela, P. H. (1985). Serotypes, hemolysin production and receptor recognition of Escherichia coli strains associated with neonatal sepsis and meningitis. Infection and Immunity 48, 486-491.

Lawlor, K. M., Daskaleros, P. A., Robinson, R. E. \& PAYNe, S. M. (1987). Virulence of iron transport mutants of Shigella flexneri and utilisation of host iron compounds. Infection and Immunity 55, 594-599.

Linggood, M. A., Roberts, M., Ford, S., Parry, S. H. \& Williams, P. H. (1987). Incidence of the aerobactin iron uptake system among Escherichia coli isolates from infections of farm animals. Journal of General Microbiology 133, 835-842.

Marolda, C. L., Valvano, M. A., Lawlor, K. M., Payne, S. M. \& Crosa, J. H. (1987). Flanking and internal regions of chromosomal genes mediating aerobactin iron uptake systems in enteroinvasive Escherichia coli and Shigella flexneri. Journal of General Microbiology 133, 2269-2278.

Montgomerie, J. Z., Bindereif, A., NeIlands, J. B., Kahmanson, G. M. \& Guze, L. B. (1984). Association of hydroxamate siderophore (aerobactin) with Escherichia coli isolated from patients with bacteremia. Infection and Immunity 46, 835-838.

Nassif, X., Mazert, M. C., Mounier, J. \& SansonETTI, P. J. (1987). Evaluation with an iuc:: Tn 10 mutant of the role of aerobactin production in the 
virulence of Shigella flexneri. Infection and Immunity 55, $1963-1969$.

NEILANDS, J. B. (1982). Microbial envelope proteins related to iron. Annual Review of Microbiology 36, 285-309.

Selander, R. K. Korhonen, T. K., Vaisanen-RHEN, V., Williams, P. H., Pattison, P. E. \& Caugant, D. A. (1986). Genetic relationships and clonal structure of strains of Escherichia coli causing neonatal septicemia and meningitis. Infection and Immunity 52, 213-222.

Simon, E. H. \& Tessman, I. (1963). Thymidinerequiring mutants of phage T4. Proceedings of the National Academy of Sciences of the United States of America 50, 526-532.

Smith, H. W., Green, P. \& Parsell, Z. (1983). Vero cell toxins in Escherichia coli and related bacteria: transfer by phage and conjugation and toxic action in laboratory animals, chickens and pigs. Journal of General Microbiology 129, 3121-3137.

STENDERUP, J. \& ØRSKOV, F. (1983). The clonal nature of enteropathogenic Escherichia coli strains. Journal of Infectious Diseases 148, 1019-1024.

SteVenson, P. \& GRIFFITHS, E. (1985). Detection of antibodies and antigens by immunblotting, In The Virulence of Escherichia coli, Reviews and Methods, pp. 457-464. Edited by M. Sussman. London: Academic Press.
Stuart, S. J., Greenwood, J. K. T. \& Luke, R. K. J. (1982). Iron-suppressible production of hydroxamate by Escherichia coli isolates. Infection and Immunity 36, 870-875.

Sussman, M. (1985). Esherichia coli in human and animal disease. In The Virulence of Escherichia coli; Reviews and Methods, pp. 7-47. Edited by $M$. Sussman. London: Academic Press.

VAisanen-RHEN, V., Elo, J., VAisanen, E., Sirtonen, A., Ørskov, I., ØrSKov, F., Svenson, S.B., MAKela, P. H. \& Korhonen, T. K. (1984). P-fimbriated clones among uropathogenic Escherichia coli strains. Infection and Immunity 43, 149-155.

Valvano, M. A., Silver, R. P. \& Crosa, J. H. (1986). Occurrence of chromosome or plasmid-mediated aerobactin iron transport systems and hemolysin production among clonal groups of human invasive strains of Escherichia coli $\mathrm{K} 1$. Infection and Immunity 52, 192-199.

Williams, P., Chart, H., Griffiths, E. \& Stevenson, P. (1987). Expression of high affinity iron uptake systems by clinical isolates of Klebsiella. FEMS Microbiology Letters 44, 407-412.

Williams, P. H. (1979). Novel iron uptake system specified by ColV plasmids: an important component in the virulence of Escherichia coli. Infection and Immunity 26, 925-932. 